\title{
Abundance and characteristics of polysaccharide and proteinaceous particles in Lake Kinneret
}

\author{
Tom Berman*, Yehudit Viner-Mozzini
}

Israel Oceanographic and Limnological Research, The Yigal Allon Kinneret Limnological Laboratory, PO Box 345 , Tiberias 14102, Israel

\begin{abstract}
Two kinds of hitherto undetected transparent particles were studied in Lake Kinneret, Israel. By using the dyes Alcian blue and Coomassie blue we visualized particles with polysaccharide (transparent exopolymer particles [TEP]) or protein components (Coomassie blue stained particles [CSP]), respectively. A large proportion of TEP and CSP in this lake appeared to be derived from previously particulate, detrital material. Combining microscopic observation with image analysis, we quantified particle abundance, projected spherical encased volume (PSEV) and surface area (SA). Although highly variable in abundance and characteristics, both kinds of particles were ubiquitously present throughout the year. TEP abundance ranged from $4.4 \times 10^{2}$ to $2.5 \times 10^{4}$ particles $\mathrm{ml}^{-1}$, with concentrations of PSEV from 80 to $5503 \mathrm{~mm}^{3} \mathrm{l}^{-1}$ and SA from 897 to $15073 \mathrm{~mm}^{2} \mathrm{l}^{-1}$. CSP abundance varied from $1.4 \times 10^{2}$ to $1.2 \times 10^{4}$ particles $\mathrm{ml}^{-1}$, with concentrations of PSEV from 8 to $5199 \mathrm{~mm}^{3} \mathrm{l}^{-1}$ and SA from 200 to $14514 \mathrm{~mm}^{2} \mathrm{l}^{-1}$. CSP were generally about 3 -fold fewer in abundance than TEP but the average PSEV and SA of CSP were usually greater than those of TEP. In contrast to TEP, significant linear correlations were found between CSP parameters (abundance, PSEV and SA concentrations) and either chlorophyll concentration or phytoplankton biomass measured at the same date. Higher densities ( 3- to 10-fold) of attached bacteria were observed on CSP than on TEP. The PSEV concentrations of TEP and CSP in the lake water were much greater than the volume of ambient phytoplankton. Transparent particles may be important in a variety of ecosystem processes: in the formation of macroaggregates (lake snow), in the sedimentation or horizontal advection of materials, as specialized environments for microbial function leading to nutrient recyling, as a particulate food for micrograzers, and as sites for adsorption of trace metals. The high concentrations of TEP and CSP found in Lake Kinneret suggest that these particles together with their associated microflora play a critical and dynamic role in this lake ecosystem.
\end{abstract}

KEY WORDS: Particles • Alcian blue - Coomassie blue • Transparent exopolymer particles . Coomassie blue stained particles · Lake Kinneret

\section{INTRODUCTION}

There is now ample evidence for a spectrum of nonliving sestonic particles in both marine and freshwaters, ranging from sub-micrometer size (Leppard et al. 1977, Koike et al. 1990, Wells \& Goldberg 1993) to large marine and lake snow aggregates (Alldredge \& Silver 1988, Grossart \& Simon 1993) and even

\footnotetext{
*E-mail: berman@amiad.org.il
}

'macroaggregates' >1 m (Revelante \& Gilmarten 1991). In natural waters, a variety of abiotic and biotic processes (coagulation, aggregation, accretion) act to form the larger from the smaller particles. At the same time, the larger particles are liable to breakdown by shear forces, bacterial degradation and ingestion by protists, microzooplankton and larval fish.

Alldredge et al. (1993) and Passow \& Alldredge (1994) discovered a class of transparent exopolymer particles (TEP) in sea water that could be visualized by staining with Alcian blue (AB), a dye specific for 
mucopolysaccharides. Typically TEP are relatively small particles or aggregates ranging in size from $\sim 5 \mu \mathrm{m}$ to 100 to $200 \mu \mathrm{m}$. Another class of small particles that stain yellow with the nucleic acid stain DAPI was reported by Mostajir et al. (1995). Subsequently, Long \& Azam (1996) described a class of protein containing particles in marine coastal waters that were observed upon staining with Coomassie blue (CB).

As yet, most published work refers to $A B$ stained particles (TEP); much less is known about CB stained particles (CSP) or those stained yellow with DAPI. In some environments, TEP appear to form mainly abiotically from DOM, by processes of coagulation and aggregation (Kiørboe \& Hansen 1993, Jackson 1995, Logan et al. 1995, Schuster \& Herndl 1995, Chin et al. 1998, Mari 1999, Passow 2000) or by bubble adsorption (Zhou et al. 1998). Considerable amounts of TEP may also be produced from diatoms (Kiørboe \& Hansen 1993, Passow et al. 1994) and from bacterial mucus (Grossart 1999, Stoderegger \& Herndl 1999). TEP are often associated with algal detritus and 'lake snow' aggregates (Grossart et al. 1997). The original findings indicating the ubiquity and frequent high abundance of TEP led to a burgeoning of interest, and numerous research papers have now been published on the topic of transparent particles in aquatic environments (e.g., Alldredge et al. 1998, Mari \& Burd 1998, Grossart 1999, Mari 1999, Passow 2000).

There is a consensus that TEP may be extremely important in the functioning of aquatic ecosystems. These particles may aggregate with each other or with other detrital fragments into marine or lake 'snow' (Logan et al. 1995, Grossart et al. 1997) serving as microbial and chemical hot spots within the 'organic matter continuum... the thin gel of tangled polymers' (Azam 1998) that characterizes marine and freshwaters. TEP and TEP-containing micro- and macroaggregates can enhance the vertical fluxes of substances and microorganisms by sedimentation. They may serve as adsorption focii for trace metals (Niven et al. 1977) and dissolved organic materials, and may provide favorable and specialized sites (e.g., anaerobic environments) for bacterial development. This in turn can lead to intensified recycling of carbon and nutrients on the particles. Additionally these particles, together with their associated flora and fauna, can serve as 'food packages' for protists, microzooplankton and even larval fish (Grossart et al. 1998, Passow \& Alldredge 2000). As pointed out by Mari (1999), grazing by plankton on TEP (and presumably also on CSP) that have been derived from DOM may constitute a by-pass of the microbial loop. Furthermore, the proteinaceous components of CSP may be extremely significant for nitrogen cycling in the marine environment (Long \& Azam 1996).
With few exceptions (Logan et al. 1995, Grossart et al. 1997, Grossart et al. 1998, Worm \& Sondergaard 1998), previously published research on TEP and CSP has dealt with the marine environment and comparatively little is yet known about their presence and role in freshwater systems. Our study of these particles in Lake Kinneret may be the first to give a detailed description of the occurrence, abundance and characteristics of particles stained with either AB (of mainly polysaccharide composition) or CB (mainly protein or polypeptide composition) in a freshwater lake.

The aim of our work was to investigate the spatial and seasonal abundances of these previously undetected transparent particles in the pelagic waters of Lake Kinneret. Our results indicate the potential importance of both $\mathrm{AB}$ and $\mathrm{CB}$ staining particles in the Lake Kinneret ecosystem and suggest that these particles play a major role in both carbon and nitrogen cycling in this lake.

\section{METHODS}

A series of 21 profiles $(1 \mathrm{~m}, 20 \mathrm{~m}$ or thermocline depth, $38 \mathrm{~m}$ near bottom) was taken at a central lake station from December 1997 through January 2000 but in only 9 of these profiles (April 1999 through January 2000) were TEP and CSP analyzed quantitatively. Concentrations of TEP in bulk water from these samples (plus 4 additional dates) were determined by the spectrophotometric method of Passow \& Alldredge (1995). The TEP concentrations were calibrated with gum xanthan and expressed as $\mu g \mathrm{l}^{-1}$ (dry weight) xanthan equivalents.

We used slight modifications of the method of Alldredge et al. (1993) to obtain TEP for qualitative and quantitative microscopic analysis. Lake samples (5 to $10 \mathrm{ml})$ were filtered under gentle $(<100 \mathrm{~mm})$ vacuum pressure onto $0.4 \mu \mathrm{m}$ polycarbonate filters (Poretics Corp., Livermore, CA, USA) and then stained on the filter for $10 \mathrm{~min}$ with $0.5 \mathrm{ml} 0.02 \% \mathrm{AB}$ in $0.06 \%$ acetic acid. Blanks were prepared with 5 to $10 \mathrm{ml}$ of $0.2 \mu \mathrm{m}$ filtered lake water. Each filter was then placed directly onto a drop of $0.2 \mu \mathrm{m}$ filtered water on a Cytoclear slide (Poretics Corp.). These slides permit direct observation in the light microscope without any interference by the polycarbonate filter (Logan et al. 1994). A small drop of immersion oil was placed on the filter, which was then sealed with a cover slip.

To observe and analyze CSP, we used the CB stain following the procedure of Long \& Azam (1996). Samples ( 5 to $10 \mathrm{ml}$ ) were filtered on $0.4 \mu \mathrm{m}$ polycarbonate filters and then stained on the filter for 10 min with $0.5 \mathrm{ml} 0.04 \%$ Coomassie brilliant blue G-250. The staining solution was prepared fresh daily by 25 -fold 
dilution from a $1 \%$ CB stock solution into $0.2 \mu \mathrm{m}$ filtered lake water giving a final $\mathrm{pH}$ of 7.4. The filters were mounted on Cytoclear slides as described above.

The slides were viewed in a Zeiss Axioscope microscope (Carl Zeiss, Oberkochen, Germany) at magnifications of 200 and 400x and occasionally also at 1000x. For quantitative analysis of particle abundance and quantification of projected cross sectional area (PA), we used Image Pro 3.0 image analysis software (Media Cybernetics, Silver Spring, MD, USA).

Similarly to Mari \& Kiørboe (1996), we calculated the projected spherical enclosed volume (PSEV) and surface area (SA) of TEP and CSP as follows:

$$
\begin{gathered}
r^{2}=(\mathrm{PA} / \pi) \\
\mathrm{PSEV}=4 / 3 \pi r^{3} \\
\mathrm{SA}=4 \pi r^{2}
\end{gathered}
$$

where $r$ is the projected particle radius. This method of calculating particle volume may cause some overestimation because of the tendency for particles to flatten out and become distorted on the filter surface (Mari \& Kiørboe 1996).

For some samples, to observe the bacteria attached to TEP and CSP, we applied $1 \mu \mathrm{g} \mathrm{ml}^{-1}$ DAPI staining (Porter \& Feig 1980) before filtration and staining with either $\mathrm{AB}$ or $\mathrm{CB}$ onto black $0.4 \mu \mathrm{m}$ polycarbonate filters (Long \& Azam 1996).

\section{RESULTS}

\section{Qualitative aspects of TEP and CSP}

The dominant algal species and chlorophyll concentrations in Lake Kinneret at various seasons during 1998 and 1999 are shown in Table 1. The lake is $170 \mathrm{~km}^{2}$ in area with a maximum depth of $\sim 40 \mathrm{~m}$; it is monomictic and, from about mid-April through December, strongly thermally stratified with an anaerobic hypolimnion.
Not surprisingly we found considerable variability in the nature of both TEP and CSP sampled at various depths in Lake Kinneret throughout the year. Much of this variability may be related to seasonal changes in the composition of the phytoplankton as was also noted by Grossart et al. (1997) in their study of TEP and lake snow in Lake Constance. For example, we could clearly identify AB stained fragments of Peridinium gatunense theca and sheet-like particles around moribund cells at all depths during and shortly after the dinoflagellate blooms in 1998 and 1999. In other seasons, we could distinguish stained filamentous particles derived from cyanobacteria, capsular material from Closterium and Gleocystis, fragments of Staurastrum, Asterionella, Aulacoseira (formerly Melosira), etc.

To document the variability of stained particles found in Lake Kinneret, detailed descriptions of the types of TEP and CSP that were observed on 6 out of 12 sampling dates from December 1997 through November 1998 are given in Table 2 .

Note that the duration of exposure to $A B$ and $C B$ stains in this study was considerably longer than that used in the original protocols of Alldredge et al. (1993) and Long \& Azam (1996). In preliminary experiments, we determined that these staining times gave optimum results in revealing TEP and CSP in our freshwater system.

\section{Quantitative aspects of TEP and CSP}

TEP concentrations in bulk water samples

The concentrations of TEP (as $\mu g \mathrm{l}^{-1}$ in gum xanthine equivalents) measured by the spectrophotometric method (Passow \& Alldredge 1995) in lake water ranged from 48 to $1160 \mu \mathrm{g} \mathrm{l}^{-1}$ (average concentration, $219 \mu \mathrm{g}^{-1}$ ). Maximum TEP concentrations were noted in the deepest water in October 1997, in December 1998 to February 1999, in May 1999, and in November

\begin{tabular}{|c|c|c|c|c|}
\hline Year & January-March & April-June & July-September & October-December \\
\hline 1998 & Aulacoseira & Peridinium & $\begin{array}{l}\text { Cyclotella, Cyanodictyon } \\
\text { Staurastrum, Chroococcus }\end{array}$ & $\begin{array}{l}\text { Synedra, Cyanodictyon, } \\
\text { Closterium, Merismopedia }\end{array}$ \\
\hline Chlorophyll: & $20-34 \mu g \mathrm{l}^{-1}$ & $30-92 \mu \mathrm{g} \mathrm{l}{ }^{-1}$ & $\begin{array}{c}\text { Merismopedia, Raphidiopsis } \\
\text { 8-13 } \mathrm{\mu g} \mathrm{l}^{-1}\end{array}$ & $\begin{array}{c}\text { Raphidiopsis, Chroococcus } \\
7-14 \mathrm{\mu g} \mathrm{l}^{-1}\end{array}$ \\
\hline 1999 & Aulacoseira & $\begin{array}{l}\text { Peridinium } \\
\text { Tetraedron }\end{array}$ & $\begin{array}{c}\text { Closterium, Synedra, } \\
\text { Aphanotheca, Radiocystis, } \\
\text { Cyanodictyon }\end{array}$ & $\begin{array}{c}\text { Aphanizomenon, Lyngbia, } \\
\text { Aphanotheca, Radiocystis, } \\
\text { Cyanodictyon }\end{array}$ \\
\hline Chlorophyll: & $7.5-20 \mu \mathrm{g} \mathrm{l}^{-1}$ & $12.0-28.0 \mu \mathrm{g} \mathrm{l}^{-1}$ & $8-11.5 \mu \mathrm{g} \mathrm{l}^{-1}$ & $7.0-9.0 \mu \mathrm{g} \mathrm{l}^{-1}$ \\
\hline
\end{tabular}

Table 1. Dominant algal species and chlorophyll concentrations in Lake Kinneret in 1998-1999, based on data of T. Zohary, T. Fishbein (phytoplankton) and Y. Z. Yacobi (chlorophyll) (pers. comm.) 


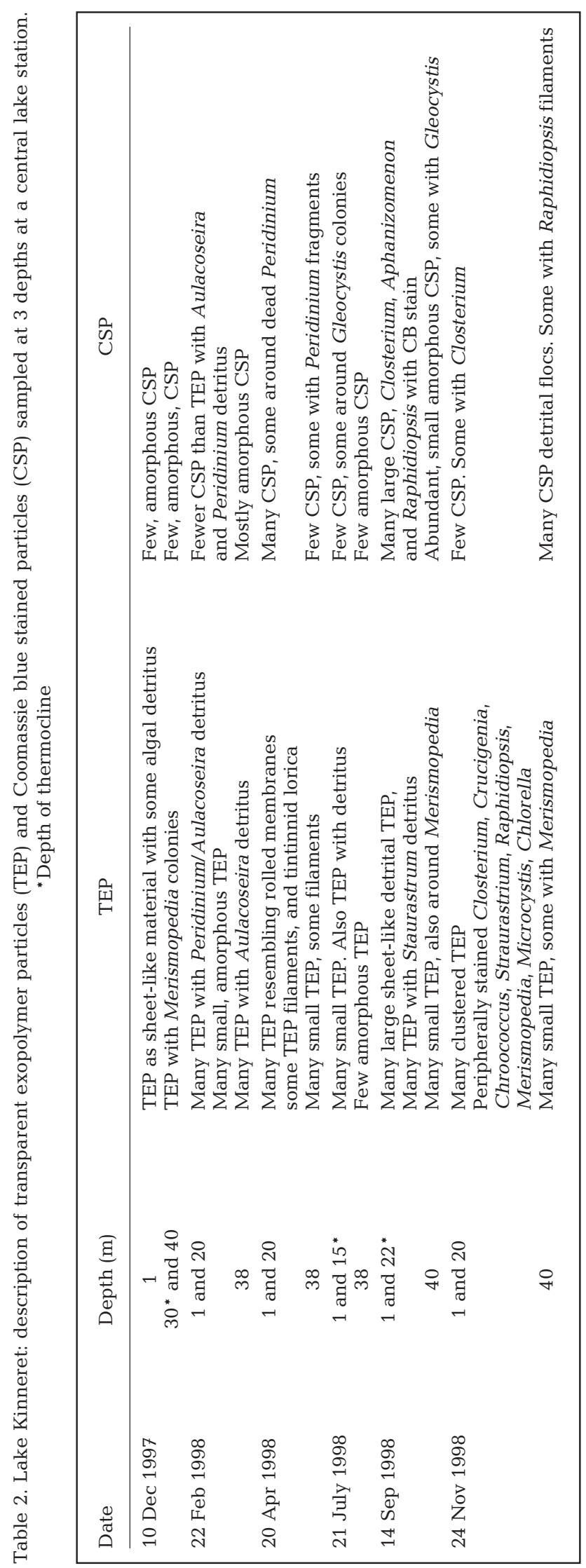

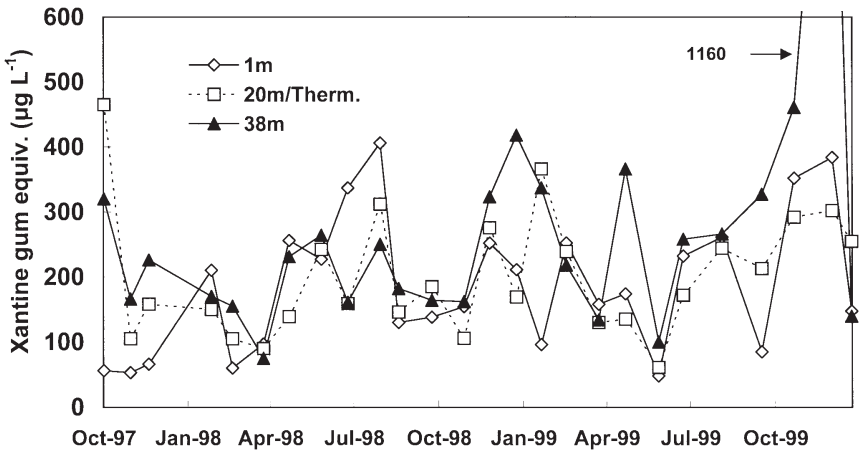

Fig. 1. Concentrations of transparent exopolymer particles (TEP) (expressed as $\mu g \mathrm{l}^{-1}$, dry weight gum xanthan equivalents) measured at 1,20 or thermocline depth, and $38 \mathrm{~m}$ at a central lake station from October 1997 through January 2000

Table 3. Correlations between TEP concentrations in bulk lake water ( $\mu \mathrm{g}$ xanthine gum equivalents $\mathrm{l}^{-1}$ ) and TEP abundance (particles $1^{-1}$ ), TEP volume (projected spherical encased volume [PSEV], $\mathrm{mm}^{3} \mathrm{l}^{-1}$ ) or TEP surface area $\left(\mathrm{SA}, \mathrm{mm}^{2} \mathrm{l}^{-1}\right.$ ) as determined by microscopy and image analysis (1 outlier data point from August 1999 removed). Table shows correlation coefficients $\left(\mathrm{r}^{2}\right)$, probabilities (p) and sample numbers (n) for direct linear regressions between parameters

\begin{tabular}{|lccc|}
\hline Linear regression type & $\mathrm{r}^{2}$ & $\mathrm{p}$ & $\mathrm{n}$ \\
\hline TEP abundance vs & 0.10 & 0.119 & 26 \\
TEP concentration & 0.61 & $<0.0001$ & 26 \\
$\begin{array}{l}\text { TEP PSEV vs } \\
\text { TEP concentration }\end{array}$ & 0.48 & $<0.0001$ & 26 \\
$\begin{array}{l}\text { TEP SA vs } \\
\text { TEP concentration }\end{array}$ & & & \\
\hline
\end{tabular}

through December 1999 (Fig. 1). Peaks of TEP in near surface water were observed in June to July 1998 and in November to December 1999. At 20 m or thermocline depth, TEP maxima occurred in October 1997, July 1998 and February 1999.

When we regressed the concentrations of TEP measured colorimetrically in the bulk water against the values obtained in the same water samples using microscopy and image analysis for TEP abundance, volume or SA (see below), we obtained significant correlations with the latter 2 parameters but not with TEP abundances $\mathrm{ml}^{-1}$ (Table 3).

\section{Quantification of stained particles in profiles using image analysis}

The extremely heterogeneous nature of the TEP and CSP in Lake Kinneret presented considerable difficulty for quantitative microscopic measurements of these particles. Sometimes apparently intact and identifiable algal or cyanobacterial cells were stained by 


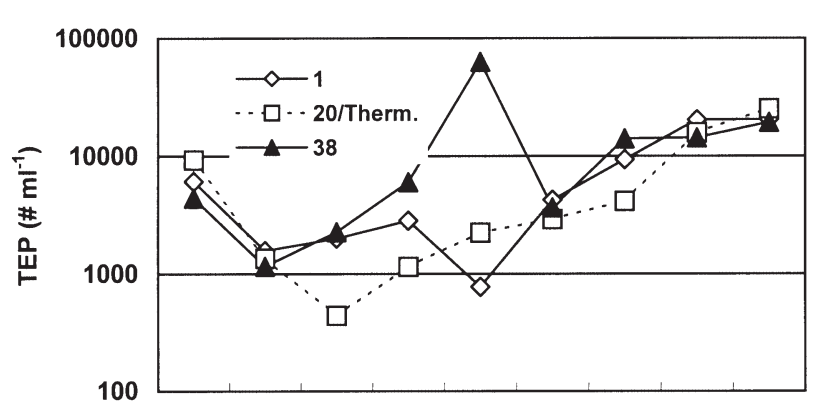

Apr May Jun Jul Aug Sep Nov Dec Jan

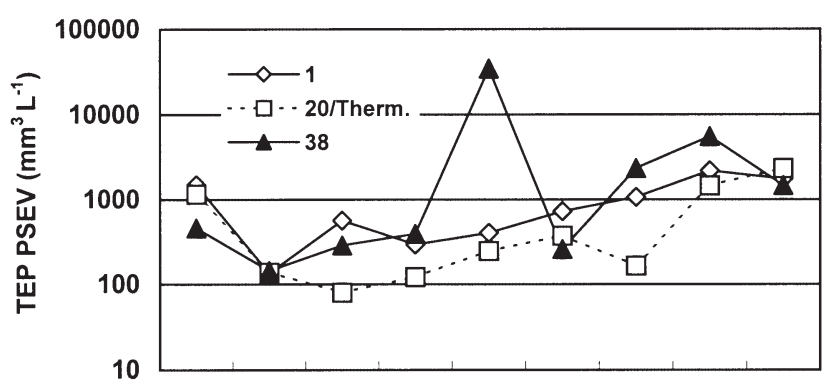

Apr May Jun Jul Aug Sep Nov Dec Jan

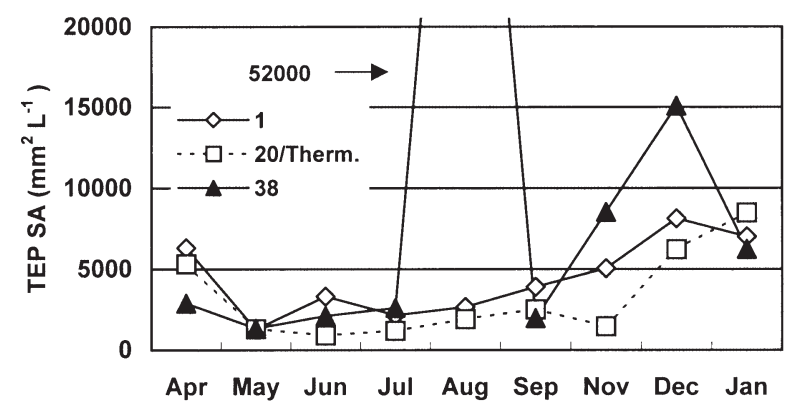

Fig. 2. TEP sampled from 1, 20 or thermocline depth, and $38 \mathrm{~m}$ at a central lake station from April 1999 through January 2000, showing abundance (particles $\mathrm{ml}^{-1}$ ), and concentrations of spherical enclosed volume (PSEV, $\mathrm{mm}^{3} \mathrm{l}^{-1}$ ) and projected surface area $\left(\mathrm{SA}, \mathrm{mm}^{2} \mathrm{l}^{-1}\right)$

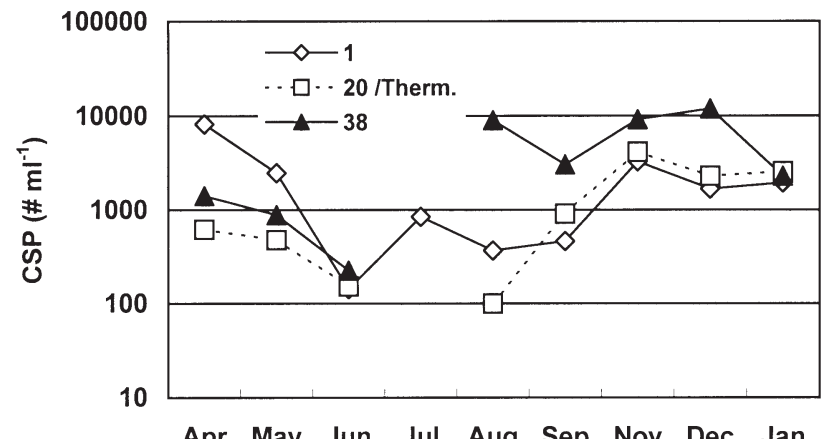

Apr May Jun Jul Aug Sep Nov Dec Jan
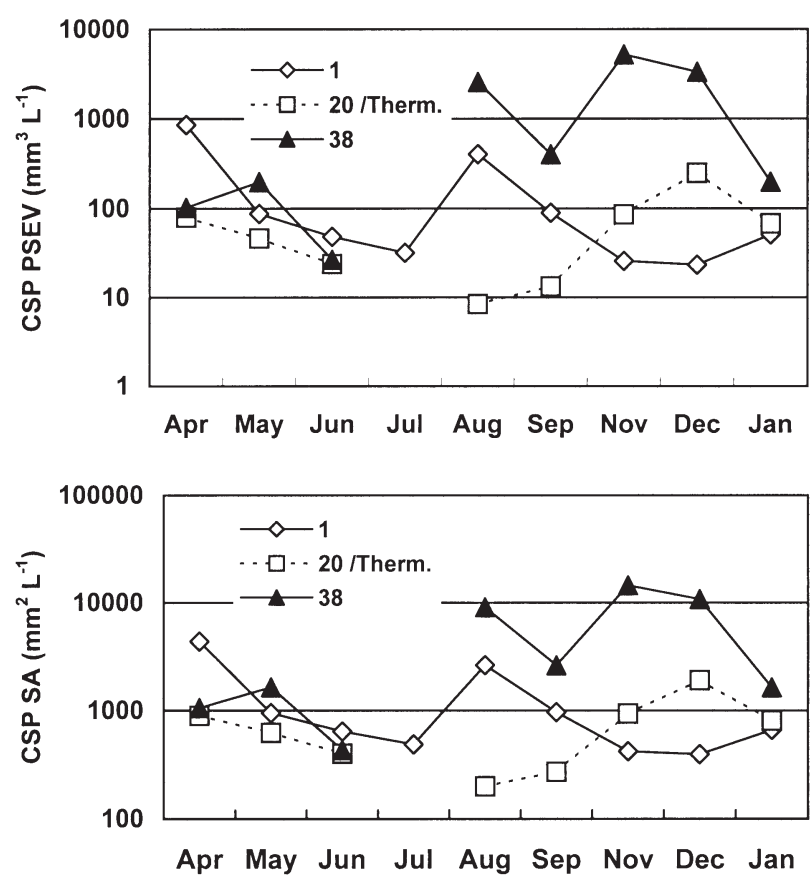

Fig. 3. Coomassie blue stained particles (CSP) sampled from 1, 20 or thermocline depth, and $38 \mathrm{~m}$ at a central lake station from April 1999 through January 2000, showing abundance (particles $\mathrm{ml}^{-1}$ ), and concentrations of $\operatorname{PSEV}\left(\mathrm{mm}^{3} \mathrm{l}^{-1}\right)$ and projected SA $\left(\mathrm{mm}^{2} \mathrm{l}^{-1}\right)$

Table 4. Lake Kinneret: correlations between CSP parameters and chlorophyll concentrations or phytoplankton biomass (samples from April 1999 through January 2000. Chlorophyll and phytoplankton data courtesy of Y. Z. Yacobi, T. Zohary and T. Fishbein. Phytoplankton biomass is integrated for euphotic zone). Correlation coefficients $\left(\mathrm{r}^{2}\right)$, probabilities (p) and sample numbers (n) for direct linear regressions between parameters, from $1 \mathrm{~m}$ depth or combined 1 and $20 \mathrm{~m}$ depth samples are shown

\begin{tabular}{|c|c|c|c|c|}
\hline Depth (m) & Parameter & $\mathrm{r}^{2}$ & $\mathrm{p}$ & $\mathrm{n}$ \\
\hline 1 & Abundance (particles $\mathrm{l}^{-1}$ ) vs chlorophyll $\left(\mu \mathrm{g} \mathrm{l}^{-1}\right)$ & 0.84 & 0.0005 & 9 \\
\hline 1 & $\operatorname{PSEV}\left(\mathrm{mm}^{3} \mathrm{l}^{-1}\right)$ vs chlorophyll $\left(\mu \mathrm{g} \mathrm{l}^{-1}\right)$ & 0.71 & 0.0042 & 9 \\
\hline 1 & SA $\left(\mathrm{mm}^{2} \mathrm{l}^{-1}\right)$ vs chlorophyll $\left(\mu \mathrm{g} \mathrm{l}^{-1}\right)$ & 0.65 & 0.0083 & 9 \\
\hline 1 and 20 & Abundance (particles $\mathrm{l}^{-1}$ ) vs chlorophyll $\left({\left.\mu \mathrm{gl}^{-1}\right)}^{-1}\right.$ & 0.63 & 0.0002 & 18 \\
\hline 1 and 20 & $\operatorname{PSEV}\left(\mathrm{mm}^{3} \mathrm{l}^{-1}\right)$ vs chlorophyll $\left(\mu \mathrm{g} \mathrm{l}^{-1}\right)$ & 0.66 & $<0.0001$ & 18 \\
\hline 1 and 20 & SA $\left(\mathrm{mm}^{2} \mathrm{l}^{-1}\right)$ vs chlorophyll $\left(\mu \mathrm{g} \mathrm{l}^{-1}\right)$ & 0.58 & 0.0003 & 18 \\
\hline 1 & Abundance (particles $\left.\mathrm{l}^{-1}\right)$ vs phytoplankton ${ }^{2}\left(\mathrm{~g} \mathrm{~m}^{-2}\right)$ & 0.83 & 0.0006 & 9 \\
\hline 1 & $\operatorname{PSEV}\left(\mathrm{mm}^{3} \mathrm{l}^{-1}\right)$ vs phytoplankton ${ }^{2}\left(\mathrm{~g} \mathrm{~m}^{-2}\right)$ & 0.64 & 0.0097 & 9 \\
\hline 1 & $\mathrm{SA}\left(\mathrm{mm}^{2} \mathrm{l}^{-1}\right)$ vs phytoplankton ${ }^{2}\left(\mathrm{~g} \mathrm{~m}^{-2}\right)$ & 0.56 & 0.0200 & 9 \\
\hline
\end{tabular}


Table 5. Ratios of CSP to TEP parameters (abundance, PSEV concentration and SA concentration) at 3 depths in Lake Kinneret (pooled and averaged data from 9 sampling dates, April 1999 through January 2000)

\begin{tabular}{|lccc|}
\hline Parameter & $1 \mathrm{~m}$ & $20 \mathrm{~m}$ & $38 \mathrm{~m}$ \\
\hline Abundance & 0.29 & 0.20 & 0.30 \\
PSEV concentration & 0.19 & 0.12 & 0.30 \\
SA concentration & 0.29 & 0.26 & 0.51 \\
\hline
\end{tabular}

the dyes and frequently it was evident that extracellular mucilage was stained. We excluded all clearly normal looking and presumably live but stained phytoplankton on the assumption that these could not be claimed as transparent particles even though they might eventually contribute to this pool as detritus. Conversely, stained algal cells that appeared damaged, chlorophyll bleached or clearly dead were included in our counts.

In Fig. 2, we show the abundance (particles $\mathrm{ml}^{-1}$ ) and concentrations of PSEV $\left(\mathrm{mm}^{3} \mathrm{l}^{-1}\right)$ and total SA $\left(\mathrm{mm}^{2} \mathrm{l}^{-1}\right)$ for TEP measured at 3 depths $(1 \mathrm{~m}, 20 \mathrm{~m}$ or thermocline, and $38 \mathrm{~m}$ ) in a series of profiles taken from April 1999 until January 2000. All the parameters showed an exceptionally high peak in the $38 \mathrm{~m}$ sample taken in August 1999. Otherwise, TEP abundances varied from $4.4 \times 10^{2}$ to $2.5 \times 10^{4}$ particles $\mathrm{ml}^{-1}$ (average $9.5 \times 10^{3}$ particles $\mathrm{ml}^{-1}$ ), and concentrations of PSEV varied from 80 to $5503 \mathrm{~mm}^{3} \mathrm{l}^{-1}$ (average $2221 \mathrm{~mm}^{3} \mathrm{l}^{-1}$ ) and of SA from 897 to $15073 \mathrm{~mm}^{2} \mathrm{l}^{-1}$ (average $5961 \mathrm{~mm}^{2} \mathrm{l}^{-1}$ ). The concentrations of PSEV and SA of TEP tended to be lower in samples from $20 \mathrm{~m}$ or thermocline depth than in either shallower or deeper samples.

No correlations were found between TEP abundance, or PSEV or SA concentrations and either chlorophyll concentration or phytoplankton biomass measured at the same date.

Table 6. Average (Avg) PSEV and SA of TEP and CSP at 3 depths in Lake Kinneret (pooled and averaged data from 9 sampling dates, April 1999 through January 2000. Max: Maximum; Min: Minimum

\begin{tabular}{|c|c|c|c|c|}
\hline \multirow[t]{2}{*}{ Depth } & \multicolumn{2}{|c|}{ Particle PSEV $\left(\mu \mathrm{m}^{3}\right)$} & \multicolumn{2}{|c|}{ Particle SA $\left(\mu \mathrm{m}^{2}\right)$} \\
\hline & & (Min-Max) & Avg & (Min-Max) \\
\hline \multicolumn{5}{|l|}{$1 \mathrm{~m}$} \\
\hline TEP & 4997 & $600-21975$ & 1414 & $344-3794$ \\
\hline CSP & 9466 & $143-57017$ & 2164 & $132-7164$ \\
\hline \multicolumn{5}{|c|}{$20 \mathrm{~m}$ or thermocline } \\
\hline TEP & 2617 & 590-15082 & 918 & $340-2952$ \\
\hline CSP & 2802 & $324-12294$ & 961 & $228-2576$ \\
\hline \multicolumn{5}{|l|}{$38 \mathrm{~m}$} \\
\hline TEP & 2573 & 548-9192 & 908 & $324-2122$ \\
\hline CSP & 8202 & $1802-49778$ & 1967 & $716-6544$ \\
\hline
\end{tabular}
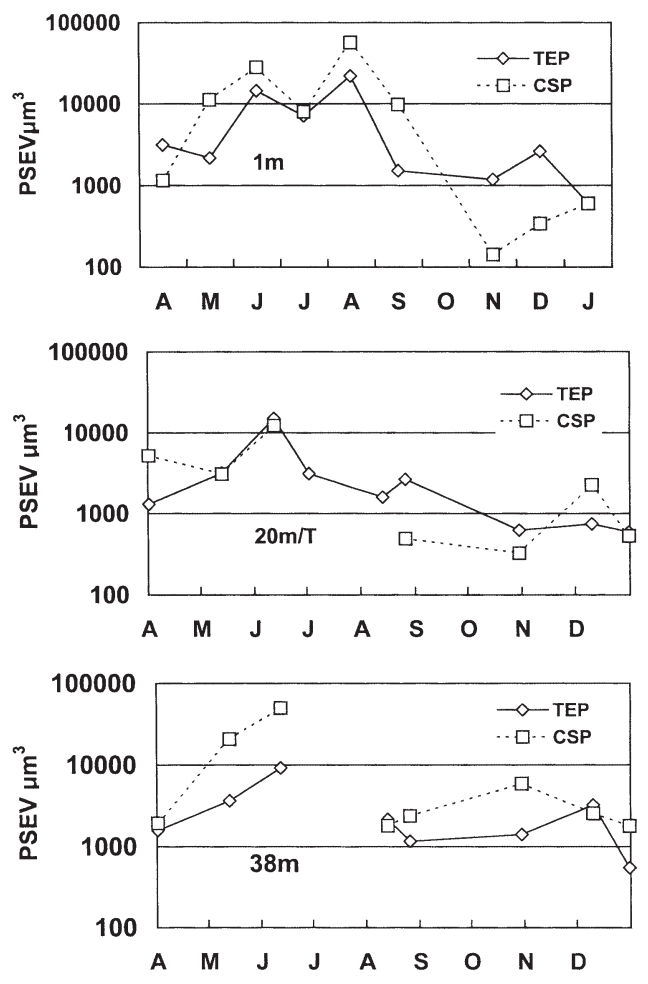

Fig. 4. Average particle PSEV $\left(\mu \mathrm{m}^{3}\right)$ for TEP and CSP sampled from 1, 20 or thermocline depth, and $38 \mathrm{~m}$ at a central lake station from April 1999 through January 2000

The abundance of CSP and their concentrations of PSEV and SA from the profiling series are shown in Fig. 3. CSP abundances varied from $1.4 \times 10^{2}$ to $1.2 \times$ $10^{4}$ particles $\mathrm{ml}^{-1}$ (average $2.8 \times 10^{3}$ particles $\mathrm{ml}^{-1}$ ), and concentrations of PSEV varied from 8 to $5199 \mathrm{~mm}^{3} \mathrm{l}^{-1}$ (average $588 \mathrm{~mm}^{3} \mathrm{l}^{-1}$ ) and of SA from 200 to 14514 $\mathrm{mm}^{2} \mathrm{l}^{-1}$ (average $2445 \mathrm{~mm}^{2} \mathrm{l}^{-1}$ ). In samples taken from $38 \mathrm{~m}$, there were markedly higher values in all these parameters from August 1999 through January 2000 than in previous months. Unlike TEP, no exceptionally high peak of CSP was observed in the samples from August 1999. High values of CSP parameters at $1 \mathrm{~m}$ depth were associated with the 1999 Peridinum bloom.

In marked contrast to TEP, we found significant linear correlations between CSP parameters (abundance, and PSEV and SA concentrations) and either chlorophyll concentration or phytoplankton biomass measured at the same date (Table 4).

Overall, for the period of this study, the concentrations of particle numbers, PSEV and SA of CSP at all depths were generally much lower 
than those of the equivalent TEP (Table 5). However, comparisons of the volume or SA of the 'average' $\mathrm{AB}$ stained particle with those of the 'average' CSP indicate that CSP were usually larger than TEP except in samples taken from $20 \mathrm{~m}$ or thermocline depth (Table 6). This was not always the case; as can be seen in Fig. 4 there were samples in which the average particle PSEV $\left(\mu \mathrm{m}^{3}\right)$ for TEP was markedly greater than that of CSP (e.g., at $1 \mathrm{~m}$ in November and December 1999).

We were unable to include a detailed study of bacterial colonization of the TEP and CSP within the scope of this work. However, in 4 out of 5 samples, taken from October through December 1998, that were stained with DAPI in addition to either $\mathrm{AB}$ or $\mathrm{CB}$, we observed a tendency for CSP to have higher ( 3- to 10 -fold) densities of associated bacteria than TEP. Similarly to Grossart et al. (1998) we found that bacterial colonization was highly variable; some microaggregates appeared to have no or very few attached bacteria while others were quite densely populated with several hundred cells particle ${ }^{-1}$.

\section{DISCUSSION}

\section{TEP measurements in bulk lake water}

The concentrations of TEP measured in Lake Kinneret were somewhat higher than those reported for a variety of marine environments (Passow \& Alldredge 1995), which seems reasonable given the more eutrophic conditions in the lake. We found no significant correlations between spectrophotometrically measured TEP concentrations and those of chlorophyll or algal biomass (data not shown). No clear seasonal pattern was evident although there was some connection of TEP concentration peaks with the occurrence of specific phytoplankton events. For example, in the near surface water layer, a peak of TEP appeared toward the end of the 1998 Peridinium bloom (June to August) but did not occur the following year when dinoflagellate abundance was greatly reduced (Fig. 1). The TEP peak at $20 \mathrm{~m}$ in February 1999 may have been related to sedimenting material from an unusually massive bloom of the large diatom Aulacosiera that occurred at that time. The very high concentrations of TEP observed at 38 m from September to December 1999 may have been caused by the presence of resuspended material from the sediment surface when the lake levels were at an all time low (213.30 m below sea level). Also there is now evidence (I. Ostrovsky pers. comm.) for the frequent presence of a turbid near-bottom layer in the lake.
TEP concentrations determined in lake water by the spectrophotometric method of Passow \& Alldredge (1995) correlated well with our microscopic measurements of TEP volume and SA (Table 3)., but not with TEP abundance (as particles $\mathrm{ml}^{-1}$ ). This reassuring result confirms that the spectrophotometric method gives a reasonably accurate measure of the actual concentrations of TEP as represented by the PSEV or SA. These concentrations would not necessarily be related to the numbers of $\mathrm{AB}$ staining particles that range widely in size.

\section{Microscopic studies of TEP and CSP}

Unlike many previous descriptions of TEP in marine waters we often found that some portion of both $A B$ and $\mathrm{CB}$ stained aggregates could be clearly identified as partly derived from particulate detritus rather than from amorphous material formed by coagulation and aggregation of DOM. Similar observations were reported for TEP in Lake Constance by Grossart et al. (1997) and in Lake Kinneret (Grossart et al. 1998). The important role that TEP can play in the formation of larger aggregates and lake snow has been elegantly documented by Grossart et al. (1997). As yet we have no estimate of the relative amounts of TEP and CSP that may be formed either from dissolved or from detrital sources in Lake Kinneret, but we assume that this relation varies depending on season, depth and turbulent state of the water column.

Previous studies of TEP have indicated that a major source for these particles is the extracellular mucus released by diatoms (Alldredge et al. 1993, Passow \& Alldredge 1994). Although some TEP associated with aggregates from marine thecate dinoflagellates have been observed, most of this material may also have originated from diatoms (Alldredge et al. 1998). However, it appears that considerable amounts of TEP may derive from detrital material of other algal groups (Grossart et al. 1997, 1998) or be generated from bacterial mucus (Grossart 1999, Stoderegger \& Herndl 1999). In the present study, we observed $A B$ and $C B$ stained microaggregates that clearly were derived from a wide variety of dominant phytoplankton species (Tables 1 \& 2). During and slightly after the dinoflagellate bloom we could identify particles of thecal plates stained with $\mathrm{AB}$ and CSP associated with clusters of apparently dead or moribund Peridinium (Tables 1 \& 2 ). Lake Kinneret phytoplankton is usually impoverished in diatoms (with the exception of occasional winter blooms of Aulacosiera) and therefore most of the transparent particles in this lake may derive either directly or indirectly from different groups of algae, bacteria or other plankton. 


\section{Quantitative TEP and CSP measurements}

We emphasize the tentative nature of our quantitative results that are derived from a rather limited sampling series covering only a 10 month period. The method used to obtain PSEV and SA depends on the measurement of the projected cross section and assumes that particles are both spherical and solid. Clearly neither of these assumptions is strictly fulfilled in the case of Lake Kinneret stained particles. Moreover, the highly variable nature of TEP and CSP (Table 1, Figs. 2, $3 \& 4$ ) and deformation caused by the filtration process (Long \& Azam 1996, Mari \& Kiørboe 1996) add to the uncertainties of our results. Nevertheless, we suggest that these measurements are useful in providing a first quantitative estimate showing the probable importance of these particles in the lake, as well as giving some basis for comparison with other aquatic environments that have been similarly analyzed (e.g., Mari \& Kiørboe 1996, Mari \& Burd 1998).

During the period of our quantitative observations (April 1999 to January 2000), the standing stock biomass of phytoplankton ranged from $\sim 35$ to $\sim 170 \mathrm{~g} \mathrm{~m}^{-2}$ (T. Zohari pers. comm.) or (in terms of algal volume) approximately 2.5 to $11.5 \mathrm{~mm}^{3} \mathrm{l}^{-1}$ if evenly distributed through a $15 \mathrm{~m}$ euphotic zone. This suggests that the volume concentrations of TEP and CSP in the lake are much greater than those of the living phytoplankton, even taking into account elevated algal concentrations in near surface waters and the possibility that our PSEV concentration values are overestimated. Of course, the particle densities would be expected to be much lower than those of algal cells.

Note that we used the method of Logan et al. 1994 in transferring the filters with either TEP or CSP directly to Cytoclear slides rather than the filter-transfer-freeze technique (Hewes \& Holm-Hansen 1983) initially used by Alldredge et al. (1993). Mari (pers. comm.) has suggested that the former method may fail to detect very small TEP or CSP and therefore may have caused an underestimate in the numbers of this size class particle. However, in our study, we used small pore $(0.4 \mu \mathrm{m})$ polycarbonate filters and scanned each sample under the microscope at 2 or sometimes 3 magnifications to detect a wide size range of particles. Moreover, by directly transferring the filters to Cytoclear slides without the manipulations required by the filter-transferfreeze technique we may actually have avoided some loss of particles before observation. Therefore, although we did not run any comparisons between the 2 methods, we do not believe that there was any significant underestimation of the numbers of small stained particles.

Previously, Grossart et al. 1998 reported abundances of TEP ranging from $6.9 \times 10^{2}$ to $6.9 \times 10^{3}$ particles $\mathrm{ml}^{-1}$ in meso-eutrophic Lake Kinneret during the fall of 1995. The abundances of TEP observed in the present study were similar, with a slightly higher maximum. These TEP abundances were greater than those observed in mesotrophic Lake Constance, with a maximum of $2.3 \times 10^{3}$ particles $\mathrm{ml}^{-1}$ (Grossart et al. 1997). These concentrations are 1 or even 2 orders of magnitude lower than TEP abundance found by Mari \& Kiørboe (1996) and Mari \& Burd (1998) in the waters of the Kattegat (Denmark) or by Worm \& Sondergaard (1998) for a eutrophic lake. Nevertheless, it is remarkable that PSEV concentrations for TEP in Lake Kinneret were of a similar range to those reported for TEP in the coastal marine environment. It follows that the size of the 'average' TEP in the lake was larger than the particles in the coastal samples (Mari \& Kiørboe 1996). This could be because many of the Kinneret TEP appeared to be partial aggregates of detrital fragments rather than originating solely from the coagulation of dissolved material. In pelagic marine environments other workers (Alldredge et al. 1993, Passow \& Alldredge 1994) have noted TEP abundances similar to or lower than those we observed in Lake Kinneret.

There was a tendency for TEP abundances, and PSEV and SA concentrations to be lowest at the thermocline (Fig. 2). Recent measurements with a Pacific Scientific Instruments particle counter also showed minimum particle counts in the water column at this depth (A. Parparov pers. comm.). Possibly this result reflects enhanced particle breakdown due to elevated bacterial activity in the thermocline. The highest TEP abundances, and PSEV and SA concentrations were sometimes found at or close to the lake bottom and it is probable that some of the particles observed there were resuspended from the sediment surface or were sampled from a near bottom turbid layer (I. Ostrovsky pers. comm.). The very high concentrations of TEP recorded at $38 \mathrm{~m}$ in August 1999 may have been in error or an artifact since they did not correspond to the spectrophotometric TEP measurements. (This data point was not included in the regressions given in Table 3). Surprisingly there was no obvious increase in TEP parameters during or immediately after the rather meager Peridinium bloom in April to June 1999 (see chlorophyll concentrations in Table 2), although some particles appeared to derive from dinoflagellate detritus.

As yet there are no published data of CSP abundance from other freshwater systems. Long \& Azam (1996) reported high concentrations of these particles: $\sim 10^{4}$ and $10^{3}$ to $10^{5}$ particles $\mathrm{ml}^{-1}$ in Pacific coast (Scripps Pier) and Arabian Sea waters, respectively. As in the case of TEP, it appears that CSP tended to be less abundant in the lake although individual particles were generally larger than CSP observed in the sea. 
The highest CSP parameter concentrations were observed in samples from the anaerobic hypolimnion (38 m) from September through December (Fig. 3). During this period the concentrations of PSEV and SA of CSP from near surface waters were minimal. These observations may reflect differential rates of CSP formation or turnover in anaerobic and aerobic waters, respectively.

Tanoue et al. (1996) characterized the proteins associated with particles from several marine regions using electrophoresis. In surface waters, a wide variety of proteins were present at low concentrations, with a few specific (in terms of molecular weight) proteins that were more distinct on the gels. The particles from which these proteins derived were not directly visualized, but presumably they could have been CSP.

\section{Comparisons between TEP and CSP}

On almost all dates and sampling depths, distinctly fewer CSP than TEP were observed with correspondingly lower concentrations of total PSEV and total SA (Table 5 and top panels, Figs. 2 \& 3). This was in marked contrast to observations in marine waters made by Long \& Azam (1996), who found that CSP were 3 to 13 times more numerous than TEP with up to 100 -fold greater total SA. In Lake Kinneret, the abundance and concentrations of PSEV and SA of CSP were between 12 and $50 \%$ that of TEP, with an exceptionally low percentage for PSEV at $20 \mathrm{~m}$ depth and a high value for SA at $38 \mathrm{~m}$ depth (Table 5). Note, however, that the 'average' CSP tended to be larger and have considerably ( 2- to 3-fold) higher PSEV and SA than the 'average' TEP, except at $20 \mathrm{~m}$ or thermocline depths (Table 6). This was particularly evident in samples taken from $1 \mathrm{~m}$ in May through September and $38 \mathrm{~m}$ in June and October 1999 (Fig. 4).

As noted by Long \& Azam (1996), because the AB or CB stains must be applied to separate samples, we have no way of knowing the extent to which the particles observed were exclusively TEP or CSP. Presumably some, if not many, of the particles had both proteinaceous and polysaccharide components. Thus, even though parallel water samples were stained, it would be incorrect to assume that the total numbers or concentrations of transparent particles is given by the summation of TEP and CSP.

The limited scope of our study did not permit any detailed, extensive investigation of bacterial colonization of TEP and CSP. Our observation of a general trend to higher densities of bacteria attached to CSP would fit the assumption that proteinaceous particles provide a more nutritious substrate than those composed mainly of polysaccharide. This would further imply that CSP have a more rapid turnover in lake water than TEP. Although this has yet to be verified experimentally for Lake Kinneret, it is consistent with the observations of Grossart (1999), who studied the formation of TEP and CSP 'manufactured' from diatom cultures in rolling tanks. Both kinds of particles were formed by axenic cultures but when bacteria were also present, the CSP disappeared more rapidly than TEP.

Somewhat surprising was the observation that all parameters of CSP concentration correlated significantly in a direct linear fashion with both chlorophyll and phytoplankton standing stocks (Table 4) whereas there was no such relation with TEP. Possibly a greater portion of TEP than CSP did not derive directly from phytoplankton. If TEP turns over more slowly than CSP, as postulated above, then perhaps more polysaccharide containing material from sources other than phytoplankton is incorporated into $\mathrm{AB}$ staining particles. Clearly a more detailed study is desirable to resolve whether these apparent differences between TEP and CSP are general and, if so, what causes them.

As noted, it appears that there are considerably more, in terms of volume concentrations, TEP and CSP than phytoplankton in Lake Kinneret. The ubiquity of stained particles and their high abundance, PSEV and SA concentration in Lake Kinneret suggest that both TEP and CSP, together with their associated microflora, play a critical and dynamic role in both carbon and nitrogen cycling in the lake ecosystem. Clearly we have just begun to reveal the potential implications of these hitherto unseen particles in Lake Kinneret specifically, and in freshwaters in general. It would be of considerable interest to determine whether there are any fundamental differences in the characteristics or function of marine or freshwater TEP or CSP due to the different salinity levels and ionic constituents in these aquatic environments.

Acknowledgements. This study was supported by a grant (No.85-97) from the Israel Science Foundation. We are most grateful to Drs H.-P. Grossart and X. Mari and 4 reviewers for helpful criticism and suggestions on previous versions of this paper. We also thank Mrs Bina Kaplan for expert technical assistance throughout this project and Drs T. Zohari, T. Fishbein and Y. Z. Yacobi for data.

\section{LITERATURE CITED}

Alldredge AL, Silver ML (1988) Characteristics, dynamics and significance of marine snow. Prog Oceanogr 20:41-82

Alldredge AL, Passow U, Logan BE (1993) The abundance and significance of a class of large, transparent organic particles in the ocean. Deep-Sea Res 40:1131-1140

Alldredge AL, Passow U, Haddock SHD (1998) The characteristics and transparent exopolymer particles (TEP) content of marine snow formed from thecate dinoflagellates. J Plankton Res 20:393-406 
Azam F (1998) Microbial control of oceanic carbon flux: the plot thickens. Science 280:694-695

Chin W, Orellana MW, Verdugo P (1998) Spontaneous assembly of marine dissolved organic matter into polymer gels. Nature 391:568-570

Grossart HP (1999) Interactions between marine bacteria and axenic diatoms (Cylindrotheca fusiformis, Nitzschia laevis, and Thalassiosira weissflogii) incubated under various conditions in the lab. Aquat Microb Ecol 19:1-11

Grossart HP, Simon M (1993) Limnetic macroscopic aggregates (lake snow): abundance, characteristics and bacterial dynamics in Lake Constance. Limnol Oceanogr 38: 532-546

Grossart HP, Simon M, Logan BE (1997) Formation of macroscopic organic aggregates (lake snow) in a large lake: the significance of transparent exopolymer particles (TEP), phyto- and zooplankton. Limnol Oceanogr 42:1651-1659

Grossart HP, Berman T, Simon M, Pohlmann P (1998) Occurrence and microbial dynamics of macroscopic organic aggregates (lake snow) in Lake Kinneret, Israel, in fall. Aquat Microb Ecol 14:59-67

Hewes CD, Holm-Hansen O (1983) A method for recovering nanoplankton from filters for identification with the microscope: The filter-transfer-freeze (FTF) technique. Limnol Oceanogr 28:389-394

Jackson GA (1995) TEP and coagulation during a mesocosm experiment. Deep-Sea Res II 42:215-222

Kiørboe T, Hansen JLS (1993) Phytoplankton aggregate formation: observations of patterns and mechanisms of cell sticking and the significance of exopolymeric material. J Plankton Res 15:993-1018

Koike I, Shigemitsu H, Kazuki T, Kogure K (1990) Role of submicrometer particles in the ocean. Nature 345:242-244

Leppard CG, Massalki A, Lean DRS (1977) Electron-opaque microscopic fibrils in lakes. Their demonstration, their biological derivation and their potential significance in the redistribution of cations. Protoplasma 92:289-309

Logan BE, Grossart HP, Simon M (1994) Direct observation of phytoplankton, TEP and aggregates on polycarbonate filters using brightfield microscopy. J Plankton Res 16: 1811-1815

Logan BE, Passow U, Alldredge AL, Grossart HP, Simon M (1995) Rapid formation and sedimentation of large aggregates is predictable from coagulation rates (half-lives) of transparent exopolymer particles (TEP). Deep-Sea Res 42: 203-214

Long RA, Azam F, (1996) Abundant protein-containing particles in the sea. Aquat Microb Ecol 10:213-221

Mari X (1999) Carbon content and C:N ratio of transparent exopolymeric particles (TEP) produced by bubbling exudates of diatoms. Mar Ecol Prog Ser 183:59-71

Mari X, Burd A (1998) Seasonal size spectra of transparent exopolymeric particles (TEP) in a coastal sea and comparison with those predicted using coagulation theory. Mar Ecol Prog Ser 163:63-76

Mari X, Kiørboe T (1996) Abundance, size distribution and bacterial colonization of transparent exopolymeric particles (TEP) during spring in the Kattegat. J Plankton Res 18:969-986

Mostajir B, Dolan JR, Rassoulzadegan F (1995) A simple method for the quantification of a class of labile marine pico- and nano-sized detritus: DAPI Yellow Particles ('DYP'). Aquat Microb Ecol 9:259-266

Niven SEH, Kepkay PE, Bugden JBC (1997) The role of TEP in ${ }^{234} \mathrm{Th}$ scavenging during a coastal bloom. Radioprotection 32:213-218

Passow U (2000) Formation of transparent exopolymer particles, TEP, from dissolved precursor material. Mar Ecol Prog Ser 192:1-11

Passow U, Alldredge AL (1994) Distribution, size and bacterial colonization of transparent exopolymer particles (TEP) in the ocean. Mar Ecol Prog Ser 113:185-198

Passow U, Alldredge AL (1995) A dye-binding assay for the spectrophotometric measurement of transparent exopolymer particles (TEP). Limnol Oceanogr 40:1326-1335

Passow U, Alldredge AL (2000) Do transparent exopolymer particles (TEP) inhibit grazing by the euphausiid Euphausia pacifica? J Plankton Res 21:2203-2217

Passow U, Alldredge AL, Logan BE (1994) The role of particulate carbohydrate exudates in the flocculation of diatom blooms. Deep-Sea Res 41:335-357

Porter GK, Feig YS (1980) The use of DAPI for identifying and counting aquatic microflora. Limnol Oceanogr 25:943-948

Revelante N, Gilmartin M (1991) The phytoplankton composition and population enrichment in gelatinous 'macroaggregates' in the northern Adriatic during the summer of 1989. J Exp Mar Biol Ecol 146:217-233

Schuster S, Herndl GJ (1995) Formation and significance of transparent exopolymer particles in the northern Adriatic Sea. Mar Ecol Prog Ser 124:227-236

Stoderegger KE, Herndl GJ (1999) Production of exopolymer particles by marine bacterioplankton under contrasting turbulence conditions. Mar Ecol Prog Ser 189:9-16

Tanoue E, Ishii M, Midorikawa T (1996) Discrete dissolved and particulate proteins in oceanic waters. Limnol Oceanogr 4:1334-1343

Wells ML, Goldberg ED (1993) Colloid aggregation in seawater. Mar Chem 41:353-358

Worm J, Sondergaard M (1998) Alcian blue stained particles in an eutrophic lake. J Plankton Res 20:179-186

Zhou J, Mopper K, Passow U (1998) The role of surface-active carbohydrates in the formation of transparent exopolymer particles by bubble adsorption of seawater. Limnol Oceanogr 43:1860-1871

Submitted: January 12, 2001; Accepted: April 24, 2001

Proofs received from author(s): June 28, 2001
Editorial responsibility: Fereidoun Rassoulzadegan,

Villefranche-sur-Mer, France

\author{
Proofs received from author(s): June 28, 2001
}

